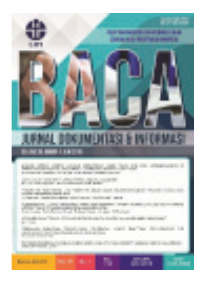

\title{
KETIKA BENCANA TERJADI: STUDI KASUS PENYELAMATAN DAN PEMULIHAN DOKUMEN MASYARAKAT
}

\author{
Aris Riyadi \\ Pusat Preservasi Perpustakaan Nasional RI \\ Korespondensi: aris_ryd@yahoo.com
}

Diajukan: 19-09-2017; Direview: 05-02-2018; Diterima: 08-02-2018; Direvisi: 15-03-2018

\begin{abstract}
At the end of 2013, natural disaster Haiyan Cyclone suddenly struck Philippines destroying various infrastructures including representative of property identity assets such as community-owned land documents that stored at Tacloban municipal land administration office. This paper reviews recovery process and handling management of important documents damaged by water in depth and comprehensive. There are some lessons and challenges that can be taken in real time from the volunteer who go directly to help community. Knowledge applied using manual rescue stages and freeze dry vacuum technology adjusts to existing field conditions. For Indonesia it self, now is the time to build many disaster management facilities and experts which is known as multidisciplinary and advanced knowledge. From this lesson we can get a various things from field of information science and documentation. So that in the future four mains basic disaster management which are prevention, preparedness, response, and recovery can be applied by various elements of society.
\end{abstract}

\begin{abstract}
ABSTRAK
Pada akhir tahun 2013, bencana alam Topan Haiyan melanda negara Filipina secara tiba-tiba menghancurkan berbagai infrastruktur termasuk aset-aset dalam bentuk dokumen kepemilikan tanah yang dimiliki oleh masyarakat yang tersimpan pada kantor administrasi pertanahan kota Tacloban. Tulisan ini membahas manajemen pemulihan dan penyelamatan dokumen penting yang rusak akibat bencana alam secara mendalam dan komprehensif. Terdapat beberapa pelajaran dan tantangan yang dapat diambil secara nyata ketika seorang relawan nantinya akan terjun langsung membantu masyarakat. Pengetahuan tentang penggunaan tahapan penyelamatan dokumen secara manual dan menggunakan teknologi freeze dry vacuum menyesuaikan kondisi lapangan yang ada. Sudah saatnya, Indonesia memiliki banyak ahli penanggulangan bencana yang sifatnya multidisiplin dan lebih maju dengan memperhatikan berbagai hal termasuk dalam bidang ilmu informasi dan dokumentasi. Sehingga empat dasar utama manajemen bencana berupa pencegahan, kesiapsiagaan, respon, dan pemulihan dapat diterapkan oleh berbagai elemen masyarakat.
\end{abstract}

Keywords: Document rescue; Information science; Disaster management; Haiyan hurricane; Freeze dry vacuum

\section{PENDAHULUAN}

Mengambil hikmah dari pengalaman bencana Tsunami Aceh tahun 2004 yang disebabkan gempa berkekuatan 9,1 sampai 9,3 skala Richter yang mengguncang dasar laut di barat daya Sumatra sebagai salah satu bencana terbesar yang pernah terjadi di dunia. Setidaknya 169 ribu korban jiwa meninggal dan kerusakan infrastruktur sebanyak 562 ribu rumah dan lahan rusak berat (BNPB, 2016). Peristiwa ini menjadi hal yang tidak pernah disukai oleh siapapun dan dimanapun. Sebuah peristiwa besar tidak berarti jika kita tidak mengambil pelajaran dan berusaha memulihkan keadaan. Keadaan darurat yang tidak terduga dapat terjadi karena 
kondisi alam dan perbuatan manusia. Bencana alam, baik besar maupun kecil, merupakan hal yang berpotensi merusak apapun tanpa kontrol yang tidak jelas.

Nyawa atau kehidupan manusia adalah factor utama yang harus kita jaga ketika menghadapi bencana. Faktor kedua adalah sesuatu yang sangat mungkin, mudah, dan bernilai untuk diselamatkan dan memiliki efek besar, yaitu dokumen pribadi atau dokumen harta benda yang nilainya melebihi perhiasan atau harta lainnya. Dokumen pribadi adalah wakil identias atas diri atau kehidupan sesorang yang terbit sebagai bagian dari suatu lingkungan (negara, pekerjaan, tempat tinggal, dsb). Dokumen harta benda adalah wakil atas kepemilikan harta baik terlihat maupun tidak yang secara hukum menjadi milik seseorang atau golongan seperti surat tanah, deposito, asuransi, dsb. Terkadang masyarakat melihatnya hanya sepele dan tidak pernah terpikir akan menyelamatkannya.

Apakah kita pernah berpikir bahwa batas lahan atau tanah rumah kita ditentukan dari selembar dokumen yang berupa setifikat, kemudian bagaimana kita membangun lahan tersebut tanpa batas yang jelas? Hal ini menjadi sangat kompleks, apabila masyarakat di sekitar akan membangun kembali rumahnya. Perencanaan dan pelatihan proaktif adalah pendekatan yang paling penting dalam persiapan masyarakat dalam menghadapi bencana. Persiapan sebelum darurat akan membantu untuk memfasilitasi respon yang efisien. Hal ini akan mempercepat pemulihan bahan yang rusak dan mempromosikan kelangsungan aktivitas masyarakat kembali.

Tidak disadari dokumen merupakan bagian penting dalam kehidupan modern. Sebagai recorded information yang memiliki berbagai bentuk, dokumen menjadi sisi yang tidak terpisahkan dari kehidupan manusia. Dokumen sangat terkait dengan status dan hak, baik individu maupun lembaga. Sebagai contoh, kasus akte tanah dalam kaitannya dengan bencana menunjukkan bahwa dokumen terkait erat dengan status dan hak kepemilikan dan pemanfaatan atas wilayah di suatu negara. Ketika terjadi tsunami Aceh, bantuan kemanusiaan datang dari berbagai Negara, salah satunya bantuan Jepang melalui Japan Internasional Cooperation Agency (JICA) untuk menyelamatkan arsip atau dokumen kepemilikan tanah yang dimiliki masyarakat Aceh. Walhasil mereka dapat meyelamatkan ribuan dokumen tanah dengan jumlah besar dalam waktu singkat, dan dokumennya saat ini tersimpan di kantor Badan Pertanahan Nasional (BPN) setempat.

Artikel ini membahas prosedur yang baru berkembang di Indonesia dalam lingkup preservasi dokumentasi terintegrasi dalam penanggulangan bencana. Kompleksitas akan semakin hadir ketika bencana terjadi dan menimpa berbagai dokumen masyarakat. Masyarakat menggantungkan informasi dokumen kepada pemerintah. Tidak banyak manajemen dan pengetahuan tentang penanganan dokumen yang dimiliki oleh ilmuwan di Indonesia bahkan instansi pemerintah tentang pengembalian kondisi fisik dokumen penting. Melalui prosedur yang tepat diharapkan dokumen dapat dimanfaatkan kembali seperti semula, baik secara fisik maupun nilai informasinya.

\section{TINJAUAN PUSTAKA}

\subsection{Manajemen Bencana}

Setiap bencana memiliki tiga fase, yaitu sebelum, selama, dan setelah. Berbagai rencana sangat diperlukan untuk mengatasi setiap fase. Diperlukan empat komponen utama untuk kesiapan bencana, yaitu pencegahan, kesiapsiagaan, respon, dan pemulihan (Eden \& Mathew, 1996; Kaln, 2003). Pola pikir manusia biasanya belajar dan berkembang dari pengalaman yang menimpa dirinya. Perencanaan dan mitigasi bencana lebih penting dari semua hal meskipun 
membutuhkan modal dan tenaga yang besar. Gambar 1 mendeskripsikan alur manajemen bencana.

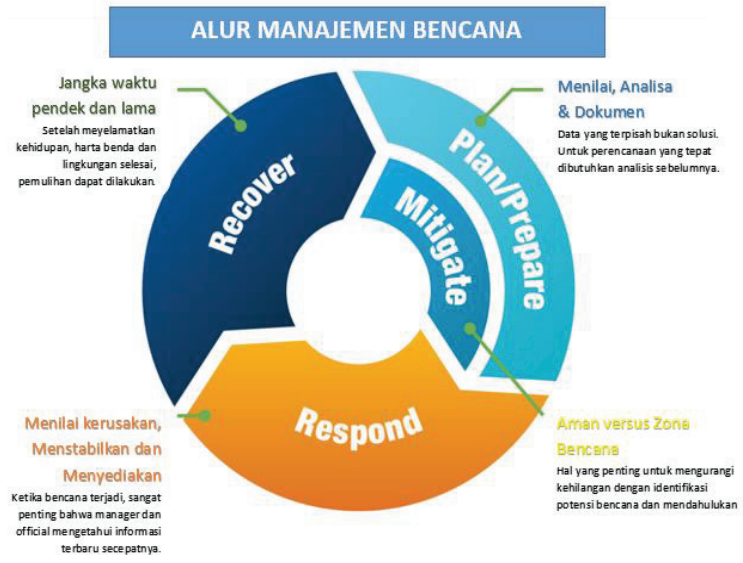

Gambar 1. Alur manajemen bencana (EI Jurnal, 2013)

Terlepas dari berbagai macam bentuk bencana yang terjadi, kerusakan pada koleksi atau dokumen biasanya disebabkan faktor utama, yaitu lingkungan buruk, api, dan air.

\subsection{Proses Pemulihan Dokumen dari Bencana}

Setiap bencana yang terjadi harus selalu dipulihkan dengan sangat cepat dan berlomba dengan waktu terutama untuk benda-benda maupun dokumen yang mudah hancur. Proses degradasi bahan baku dokumen tidak hanya menghilangkan informasi yang ada di dalamnya namun juga bukti otentik dokumen sehingga tidak dapat digunakan sebagai alat bukti. Pemanfaatan metode pemulihan dokumen dampak dari bencana terendam air seperti banjir, topan, dan tsunami dapat dilakukan secara manual maupun menggunakan teknologi maju. Pemulihan secara manual sangat tepat ketika kerusakan diperlukan cepat penanganannya dengan sumbe daya yang sangat terbatas. Namun, sangat tidak efektif dan efisien ketika objek dampak bencana jumlahnya besar dengan waktu kerusakan makin cepat.

Di Negara maju dan berkembang telah memanfaatkan teknologi pemvakuman objek beku (freeze drying vacuum) pada sebuah chamber besar. Sebuah proses pengeringan pada air yang menyatu dengan objek (dokumen), dengan cara: (1) objek dibekukan terlebih dahulu di bawah suhu beku air kemudian secara cepat air beku tersebut dikeringkan pada tekanan di bawah normal dalam ruang hampa; (2) memodifikasi fase air tanpa melewati proses pencairan dengan tekanan, maka air akan mengering secara cepat karena tersublimasi menjadi uap seperti halnya dry es. Ketika cairan diubah menjadi fase uap dengan pemanasan, tindakan ini disebut evaporasi. Proses sublimasi dan penguapan tergantung pada hubungan temperatur dan tekanan yang menghasilkan energi kinetik (energi gerak konstan) pada fase cair atau padat. Sebagai contoh dalam ketel air yang dipanaskan maka energi kinetik juga akan meningkat dan memungkinkan molekul dari cairan untuk keluar sebagai uap.

Penguapan air maksimum terjadi pada titik didih $\left(100{ }^{\circ} \mathrm{C} ; 1 \mathrm{~atm}\right)$. Sebaliknya, tekanan uap air dalam kesetimbangan dengan cairan adalah $760 \mathrm{~mm} \mathrm{Hg}$ pada $100^{\circ} \mathrm{C}$. Jika tekanan atmosfer berkurang misalnya $525,8 \mathrm{mmHg}$ maka temperatur juga mengikutinya, yang digunakan untuk mendidihkan air hanya memerlukan temperatur $90^{\circ} \mathrm{C}$. Gambar 2 menunjukkan ilustrasi kurva fase air. 


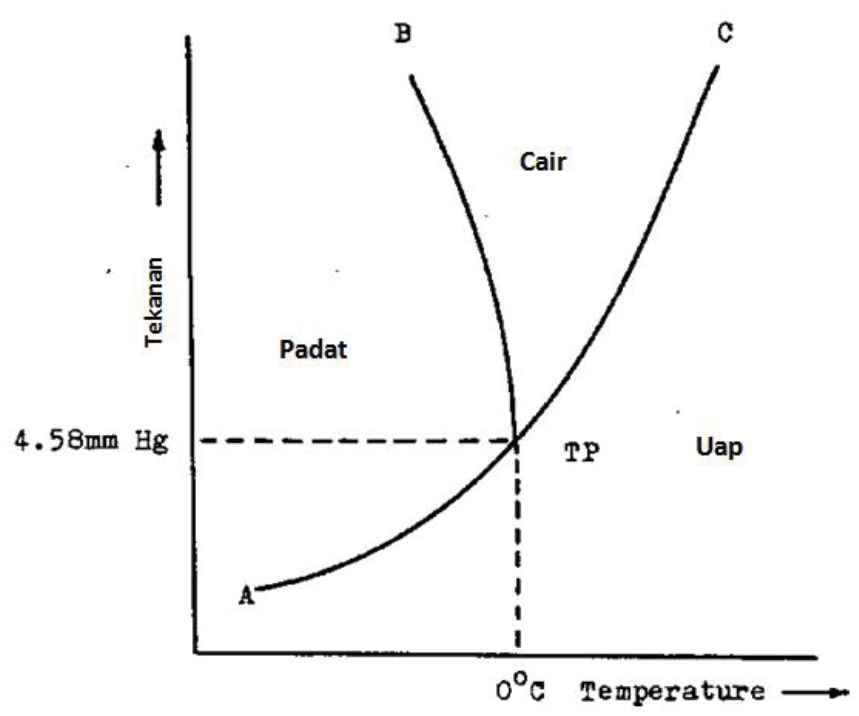

Gambar 2. Keseimbangan temperatur dan tekanan fase air (Wikipedia, 2016)

Gambar 2 menjelaskan bahwa sebuah titik pada kurva setiap mewakili kondisi keseimbangan antara dua keadaan pada suhu tertentu dan tekanan. Jika suhu dinaikkan dan tekanan meningkat maka fase padat memasuki zona cair dan akhirnya meleleh. Jika suhu berkurang pada tekanan konstan maka bentuk padat dapat berubah menjadi uap. Sublimasi menjadi sangat mungkin terjadi karena tidak ada proses zona cair di antara zona padat dan zona uap. Hal yang dapat dilakukan adalah memodifikasi temperatur dan tekanan terkontrol pada ruang hampa sehingga terjadilah proses sublimasi (Gambar 3).

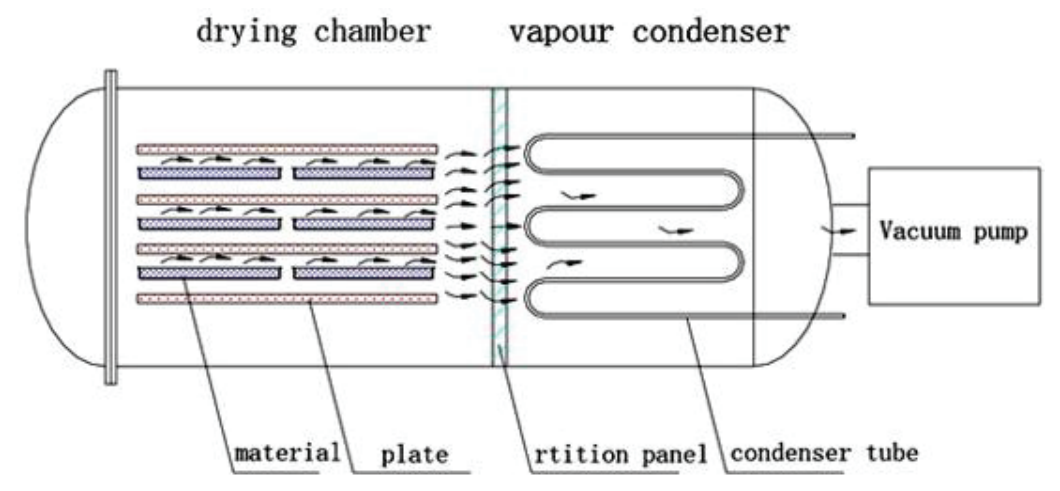

Gambar 3. Instalasi freeze drying vacuum chamber untuk perbaikan dokumen

\section{METODE}

Jenis penelitian ini adalah kualitatif dengan pendekatan studi kasus. Penelitian kualitatif adalah prosedur penelitian yang menghasilkan data deskriptif berupa kata-kata tertulis atau lisan dari orang-orang atau perilaku yang diamati (Bogdan \& Tylor, 1990). Dalam penelitian kualitatif, peneliti merupakan alat penelitian yang utama, peneliti memiliki banyak kelebihan daripada daftar pertanyaan yang lazim dilakukan di penelitian kuantitatif kuesioner (SulistyoBasuki, 2000). Studi kasus penelitian ini yaitu peneliti mengetahui secara langsung penerapan manajemen bencana sebagai fenomena konteks kejadian nyata yang digunakan sebagai sumber bukti, serta ikut serta dalam mengumpulkan data dan mendekripsikan proses penanganan 
dokumen yang rusak akibat bencana alam. Pengumpulan data melalui observasi, yaitu berupa pengamatan dan pencatatan secara sistematis terhadap gejala yang tampak pada objek penelitian pengamatan dan pencatatan dilakukan terhadap objek di tempat terjadi atau berlangsungnya peristiwa (Margono, 1997). Pengumpulan data juga diperoleh melalui interaksi langsung secara verbal dan tindakan terhadap pelaku yang bekerja menangani dokumen. Data hasil observasi ini berupa catatan lapangan, dokumentasi, dan bahan-bahan lain yang telah disederhanakanmemilih hal yang pokok dan fokus terhadap tema sehingga lebih mudah dipahami dan dibaca.

\section{HASIL DAN PEMBAHASAN}

\subsection{Bencana Topan Haiyan Filipina}

Pada tahun 2013 topan Haiyan menyerbu sejumlah wilayah di Filipina. Dampaknya sangat dahsyat, korban tewas diperkirakan mencapai 10 ribu orang. Ribuan rumah hancur rata tersapu angin super kencang. Topan 'monster' ini telah melalap habis 6 pulau di Filipina. Banyak bangunan dan perumahan yang hancur, sebagian besar korban tewas terjadi di Pulau Leyte. Bencana ini juga membuat aktivitas warga lumpuh. Listrik mati dan jalur transportasi tak bisa dilalui. Besarnya efek dari Topan Haiyan ini disamakan dengan bencana tsunami pada 2004 silam yang menimpa kawasan Samudra Pasifik, dengan dampak terbesar terjadi di Aceh.

Pada 2 Desember 2013 - hari pertama kali peneliti mendapat informasi bahwa telah datang tim JICA Jepang ke Filipina dan sedang berkoordinasi dengan Universitas Filipina, pemerintah lokal dan Japan Foundation tentang rencana penyelamatan dan pemulihan pusatpusat informasi yang dokumennya terkena dampak bencana. Dua hari setelah berkoordinasi, kemudian tim melakukan perjalanan menuju Tacloban City, salah satu wilayah pesisir pantai yang mengalami dampak terparah akibat Topan Haiyan. Gambar 4 menunjukkan kondisi daerah pesisir pantai Tacloban City.

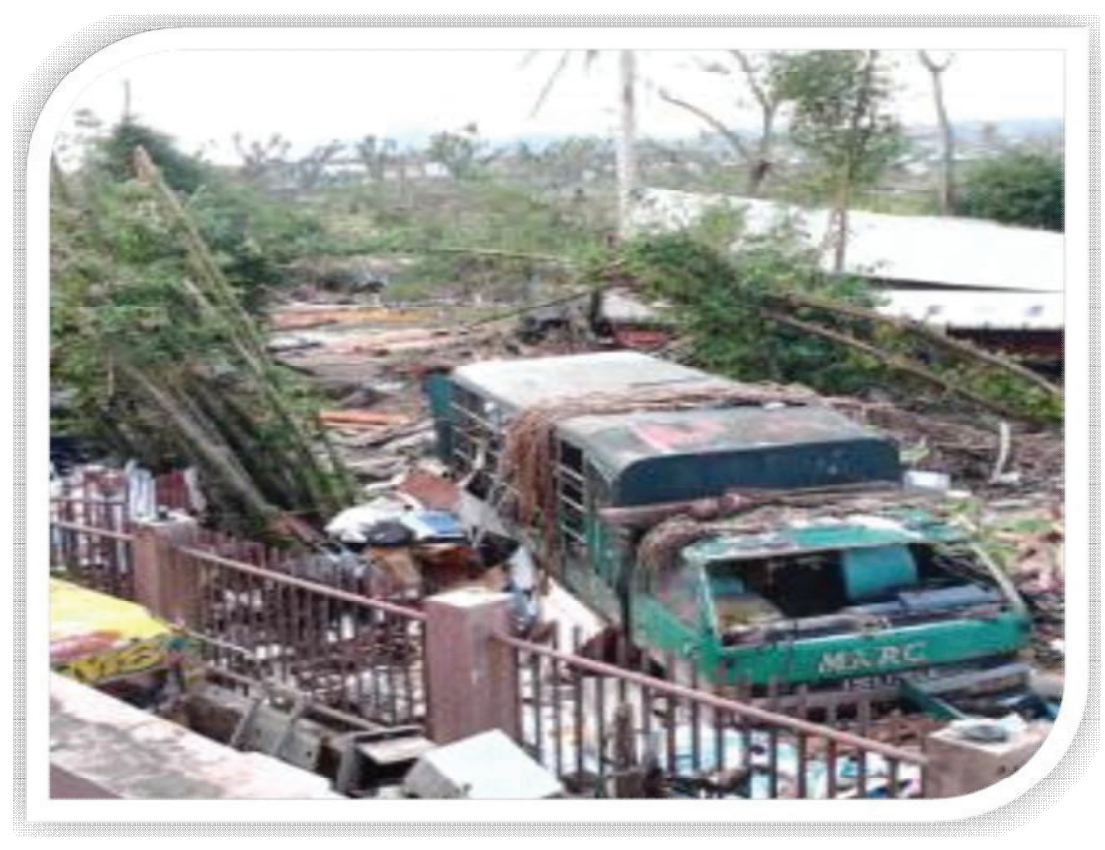

Gambar 4. Kerusakan akibat Topan Haiyan, Tacloban City Sumber: Observasi langsung (2013) 
Melalui komunikasi setiap waktu dengan tim dan relawan (senior konservator, Perpustakaan Nasional RI) tentang apa yang dikerjakan, mereka mengajak tim dari Perpusnas RI untuk bergabung dalam proses penyelamatan bencana. Perpusnas RI kemudian merespon baik, dan berkomitmen untuk saling membantu antar negara ASEAN dalam menghadapi bencana alam di wilayah tersebut. Pada 17 Desember 2017, Perpusnas RI memberangkatkan seorang konservator senior yang berpengalaman dalam pemulihan dokumen berbahan dasar kertas. Berikut ini beberapa pengalaman tim konservator dan relawan ketika membantu pemulihan dokumen dampak Topan Haiyan di Tacloban City.

- Pastikan relawan yang dikirim memiliki pengalaman dan kompetensi dalam penyelamatan dan pemulihan dokumen dengan komunikasi (bahasa Inggris) yang memadai. Relawan menuju Tacloban City yang berjarak $254 \mathrm{~km}$ dari bandara Cebu menggunakan kapal feri. Jalur yang ditempuh melewati kota Ormoc dan tiba pada pukul 8 am waktu setempat, sehingga harus menginap. Dalam perjalanan, relawan kita bertemu dengan sukarelawan Angkatan Laut Korea Selatan yang juga akan menuju Tacloban dan mau mengantarkan relawannya. Rute perjalanan relawan menuju Tacloban City terlihat pada Gambar 5.

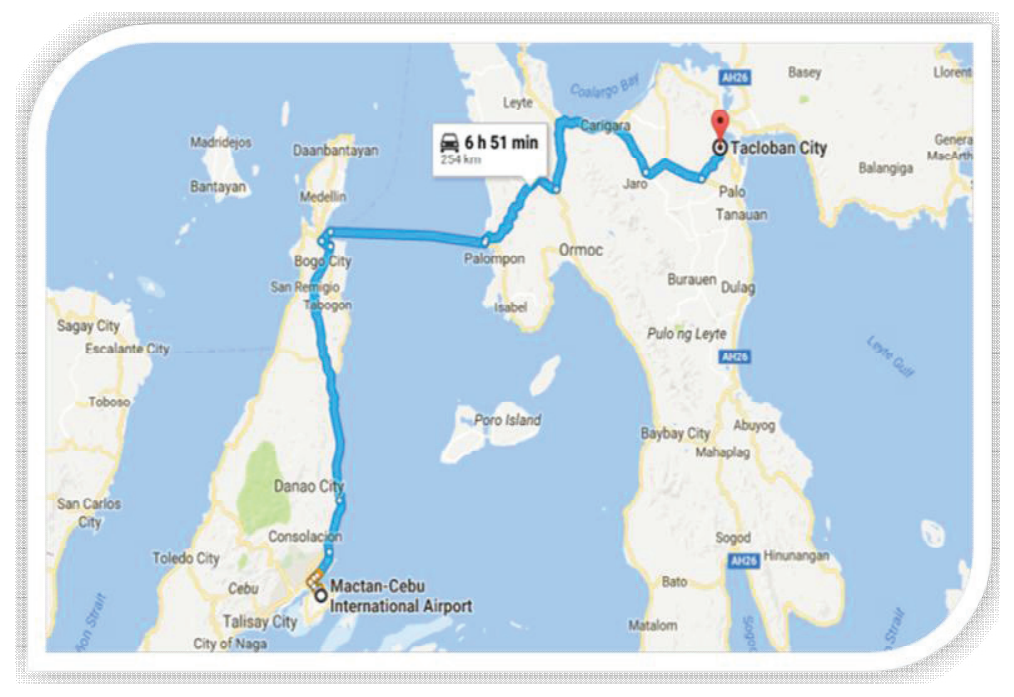

Gambar 5. Rute perjalanan relawan Perpusnas RI menuju Tacloban City Sumber: Google Map (2017)

- Menjalin komunikasi dengan penduduk lokal dan sesama relawan. Berbagai informasi tentang adat, budaya, kebiasaan, dan kondisi terkini pada wilayah yang terkena bencana. Dalam perjalanan, relawan mendapatkan bantuan berupa tumpangan kendaraan dinas polisi setempat disertai prajurit Korea Selatan. Relawan diwajibkan melanjutkan perjalanan di siang hari karena alasan keamanan. Ketika sampai di Pos Kepolisian Tacloban, relawan dijemput oleh tim yang sudah menunggu di sana, kemudian menuju rumah penampungan milik kepala Tacloban Land Administrasion (Badan Pertanahan) dan dikenalkan oleh beberapa rekan yang juga telah bekerja di sana. Kondisi kota adalah tanpa listrik, tanpa cahaya di malam hari, sulit air bersih, puing-puing berserakan, makanan dan minuman jarang dan mahal, transportasi dan bahan bakar mahal, dan cukup mencekam ketika malam hari karena sering terjadi perampokan dan suara tembakan dari suatu tempat. 
- Melakukan survei kondisi dan bekerjasama membuat rencana kerja tentang pemulihan dokumen - dalam waktu yang sempit dengan memberdayakan masyarakat sekitar untuk membantu. Kondisi gedung Land Administrasion saat itu hanya tinggal satu lantai (dari dua lantai). Lantai atas hancur tersapu oleh topan berkecepatan hingga mencapai 370 $\mathrm{km} / \mathrm{jam}$ dari arah pantai yang hanya berjarak $100 \mathrm{~m}$. Posisi atau letak pembangunan gedung bukanlah penataan yang baik apalagi gedung tersebut sebagai tempat penyimpanan dokumen milik masyarakat. Dalam tahapan mitigasi manajemen perencanaan bencana, perlu membangun dan menyimpan dokumen berharga tidak dekat dengan sumber bencana alam, seperti pantai, gunung, sungai, dataran rendah dan lainlain. Setelah melakukan survei dan identifikasi tentang kondisi pasca-bencana, relawan menggambarkan keadaan pemulihan dan penyelamatan dokumen sebagai berikut (Gambar 6).

$\begin{gathered}\text { Kerusakan dokumen } \\ \text { dipercepat oleh waktu }\end{gathered} \quad$ Pantai (hanya 100 meter)
Temp. 28 C; RH 87\%

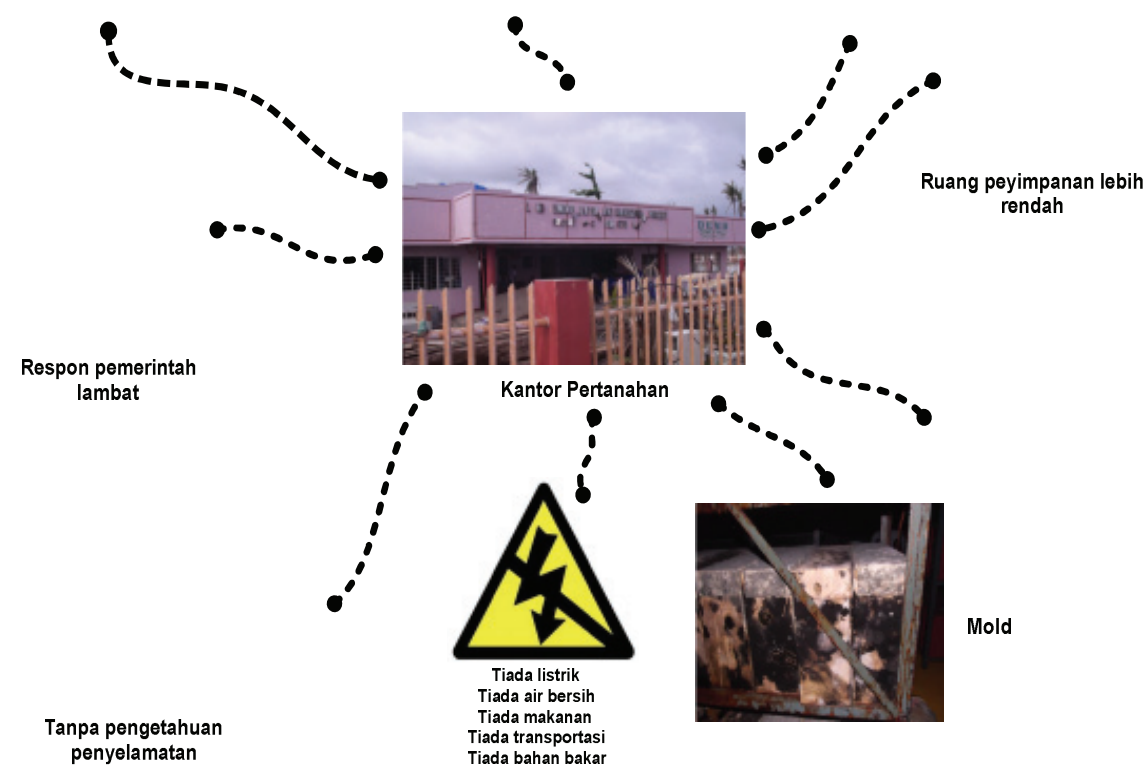

Gambar 6. Identifikasi risiko yang telah terjadi

Kegiatan survei dilakukan di berbagai tempat yang menjadi pusat dokumen bagi masyarakat, misalnya kantor kepolisian setempat, perpustakaan kota, Universitas Tacloban, dan masyarakat atau pengusaha yang mempunyai data digital tentang inventaris barang.

- Tempat publik terbuka untuk semua, membentuk kembali hak informasi kepada masyarakat inklusi. Habermas (1989) menjelaskan tentang ruang publik yang diciptakan melalui demokraksi deliberatif maka perpustakaan bisa menjadi arena untuk berpatisipasinya masyarakat dalam deliberasi. Perpustakaan merupakan ruang publik yang sudah terbebas dari kekuasaan, di mana demokrasi atau perundingan berjalan, memperoleh informasi dan menyuarakan pesan untuk berkomunikasi, memberi ide dan 
gagasan. Sebagai tempat terbuka, perpustakaan memiliki potensi menampung keberagaman pengguna untuk berkontribusi membentuk hubungan saling percaya antara beragam orang dan sebagai hasil dari proses belajar-membuat kepercayaan terhadap masyarakat. Kegiatan ini dilaksanakan di Shrine, rumah kediaman keluarga mantan presiden Imelda Marcos dan perpustakaan kota yang letanya bersebelahan (Gambar 7).

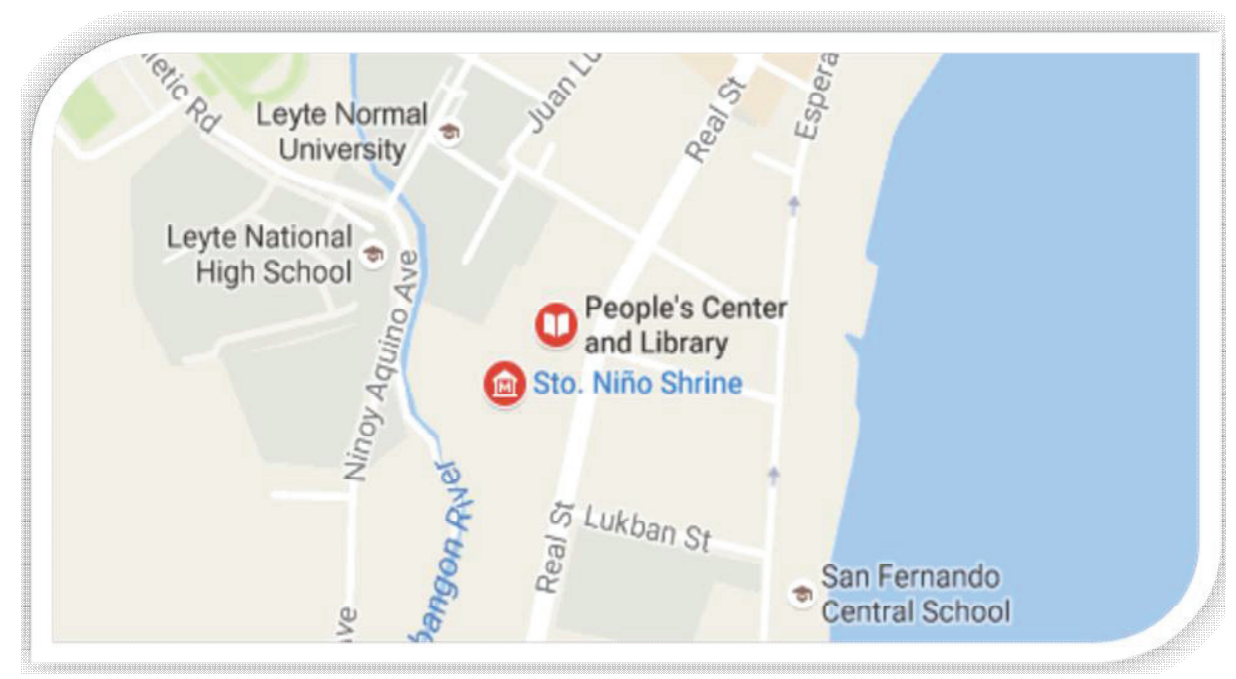

Gambar7. Ilustrasi ruang publik Shrine dan perpustakaan kota Sumber: Google Map (2017)

Hal yang menarik adalah perpustakaan kota menjadi tempat penampungan korban bencana, lantai atas dan bawahnya terisi penuh oleh para keluarga. Di satu sisi gedung Shrine tidak dapat dimasuki oleh pengungsi karena ada penjagaan yang sangat ketat bahkan ketika relawan ingin masuk ke dalamnya dikenakan tarif masuk. Gambar 8 menunjukkan ilustrasi ruang pengungsi di gedung Shrine.

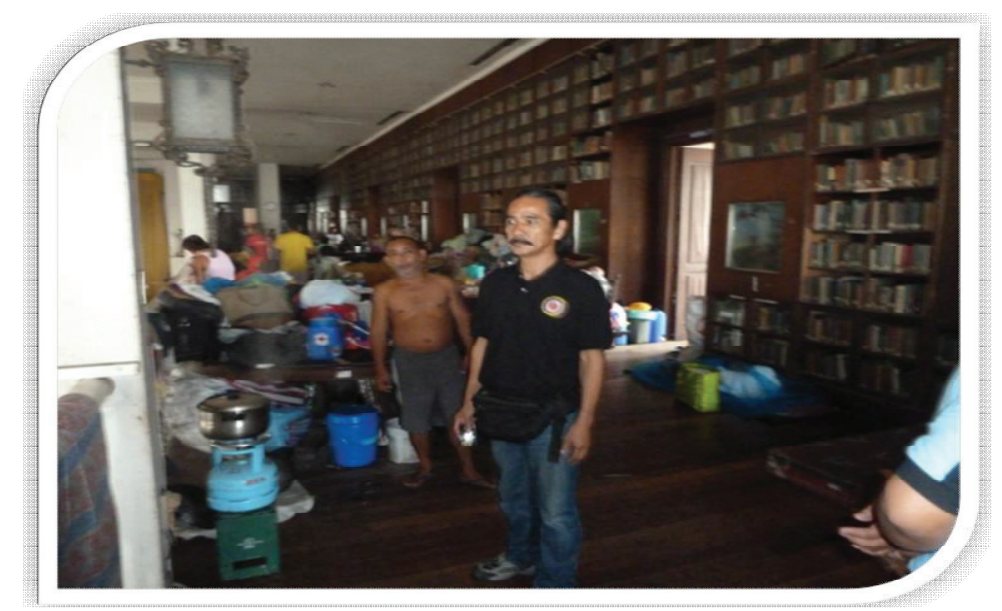

Gambar 8. Ruang publik perpustakaan yang menampung pengungsi Sumber: Observasi langsung (2013) 
Adapun fungsi ketika perpustakaan menjadi ruang publik dan tempat pengungsian, yaitu sebagai: (1) rumah tempat berlindung dan istirahat; (2) tempat belajar masyarakat sepanjang hayat; (3) tempat berkumpulnya masyarakat; dam (4) tempat perdagangan sementara memenuhi kebutuhan hidup.

\subsection{Pemulihan Bencana}

Dalam pemulihan bencana, ada standar operasional prosedur yang perlu dilakukan, sebagaimana terlihat pada Gambar 9.

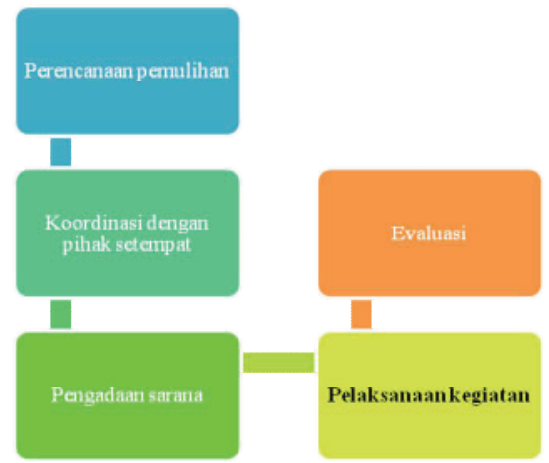

Gambar 9. Diagram standar operasional prosedur pemulihan bencana

Relawan lebih terfokus pada proses kegiatan pemulihan dokumen atau arsip kantor administrasi pertanahan. Pihak JICA memberikan sarana kepada kepala kantor untuk perbaikan dokumen yang menjadi wewenangnya - karena tidak semua kepala kantor setuju. Adapun sarana tersebut berupa rental transportasi, bahan bakar, listrik (genset), kipas angin, thermo hygrometer, material konservasi (jaring, keranjang, tali, pisau, spatula, nonwoven sheet, wrapping paper, jepitan, terpal, plastik, pinset, kuas, rak pengering, masker, sarung tangan karet, P3K, bak perendam, alkohol, pembunuh jamur dan biota, sprayer, makan, dan honor pekerja. Adapun tahapan pelaksanaan pemulihan dokumen, dijelaskan sebagai berikut.

- Tahap 1, berkoordinasi dan bekerjasama. Kami menggunakan 10 orang tenaga muda dari masyarakat sekitar. Sebelum mereka bekerja terlebih dahulu diberikan pelatihan dan pengetahuan tentang hal yang akan mereka lakukan dengan contoh yang benar.

- Tahap 2, segera memindahkan dokumen/arsip dari ruang penyimpanan bawah menuju ruang terluar dengan sirkulasi udara yang cukup baik, terlindung dari cahaya matahari, dan tidak terkena hujan. Tugas berikutnya adalah meregistrasi nomor dokumen pada rak tertentu ke dalam keranjang yang disediakan dengan nomor dan susunan keranjang yang sama. Lakukan pencatatan tentang jumlah, posisi, identitas, dan pemberian label pada keranjangnya. Hal ini bertujuan untuk memudahkan proses ketika selesai pemulihan.

- Tahap 3, ruang penyimpanan dokumen dibersihkan dan dikeringkan dengan mengambil air yang menggenang di lantai, melakukan sirkulasi udara dengan kipas angin dan membuka semua lubang ventilasi. Rak-rak yang sebelumnya ada juga dikeluarkan, dicuci kembali, dan dilakukan pengecatan ulang pada tembok.

- Tahap 4, dokumen dalam rak disusun dengan jarak yang tidak terlalu renggang dan diambil satu persatu untuk dibuka plastik atau bungkus map-nya. Kondisi dokumen yang kami temui semuanya terbungkus oleh plastik dengan bukaan di bagian atas. Keempat tahapan di atas, dijelaskan juga pada Gambar 10. 


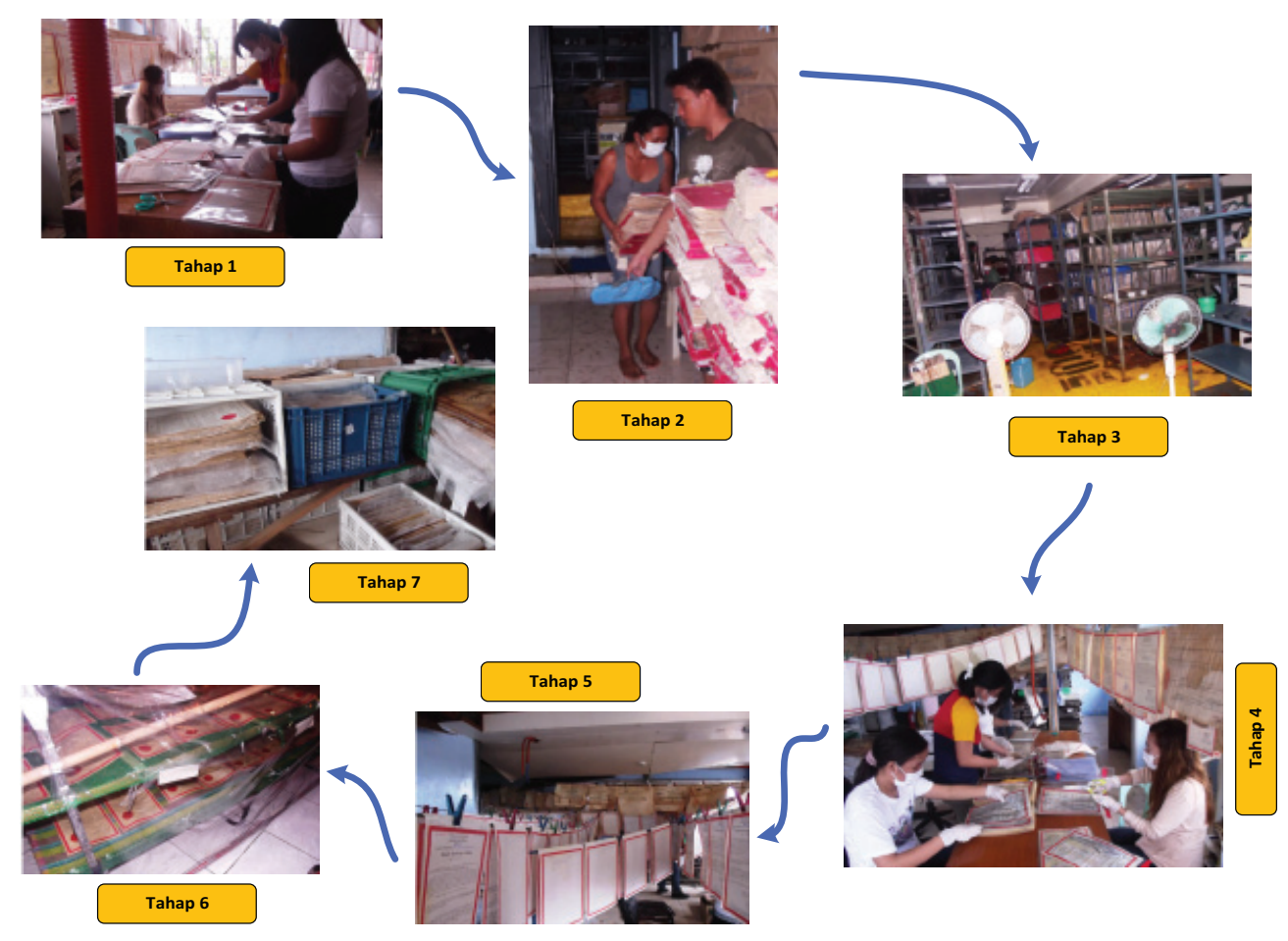

Gambar 10. Pelaksanaan kegiatan pemulihan dokumen

Pada Gambar 10 terlihat juga penggunaan plastik untuk menutupi atau melindungi dari serangan fisik atau kimia langsung lingkungan, terbukti sangat efektif untuk melindungi da memulihkan dokumen surat tanah masyarakat Filipina. Artinya ketika terkena air maka kertas tidak akan langsung basah oleh air laut (asin). Berbeda halnya dengan air tawar, air yang merendam dokumen mengandung mineral garam dari laut sehingga akan memperlambat pembusukan pada kertas oleh bakteri. Surat tanah hanya ada 1 lembar dari satu identitas aset yang dimiliki oleh pribadi atau bersama - ini berbeda dengan surat tanah di Indonesia yang jumlahnya berlembar-lembar. Hal tersebut dapat dilihat pada Gambar 11.

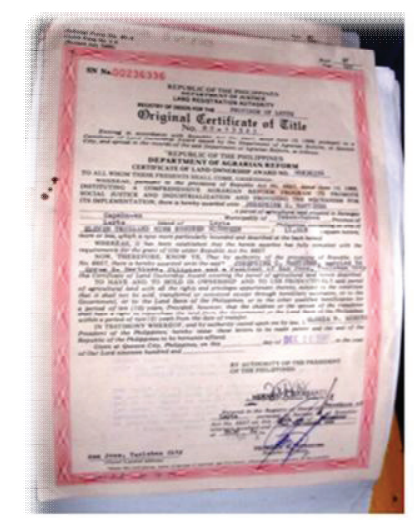

Surat tanah di Filipina

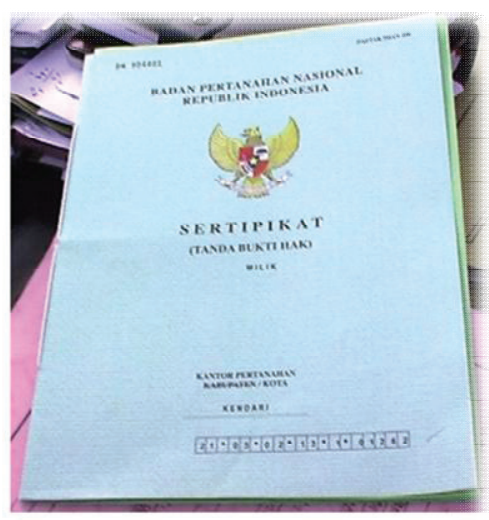

Surat tanah di Indonesia

Gambar 11. Bentuk Surat tanah yang ada di Filipina (kiri) dan Indonesia (kanan) Sumber: Observasi langsung (2013) 
Hal yang terpenting adalah 1 lembar dokumen dengan 1 identitas dapat memudahkan perlindungan hak warga Negara atau penduduk dengan baik ( meng-enkapsulasi).

- Tahap 5, membuka plastik pelindung dokumen satu persatu dengan gunting secara perlahan agar tidak robek. Gunakan alkohol $70 \%$ untuk disemprotkan dokumen sehingga jamur dan biota lain pada kertas akan mati. Alkohol juga mempermudah pengambilan dokumen yang lengket pada plastik. Gunakan alat bantu spatula untuk mengangkat dokumen. Apabila mudah diambil, dokumen digantung atau dijemur, kemudian disemprotkan alkohol (jangan terlalu basah) agar tidak menghilangkan tinta tulisan dan dikeringkan dengan kipas angin.

- Tahap 6, apabila dokumen lengket dan menyatu sama lain maka dilakukan perendaman langsung seluruh ikatan dokumen pada bak yang berisi air. Kemudian, dokumen tersebut dipisahkan satu persatu menggunakan spatula dan angkat menggunakan jaring nyamuk. Letakkan handuk pada kertas setelah itu semprotkan alkohol dan keringkan dengan cara digantung pada tali, dapat juga membuat keranda atau chamber buatan yang bertujuan untuk mempercepat pengeringan dan udara tidak terbuang percuma pada ruang chamber tertutup. Pemanfaatan kipas angin secara langsung akan mempercepat pengeringan kertas. Proses tersebut dapat dilihat pada Gambar 12.
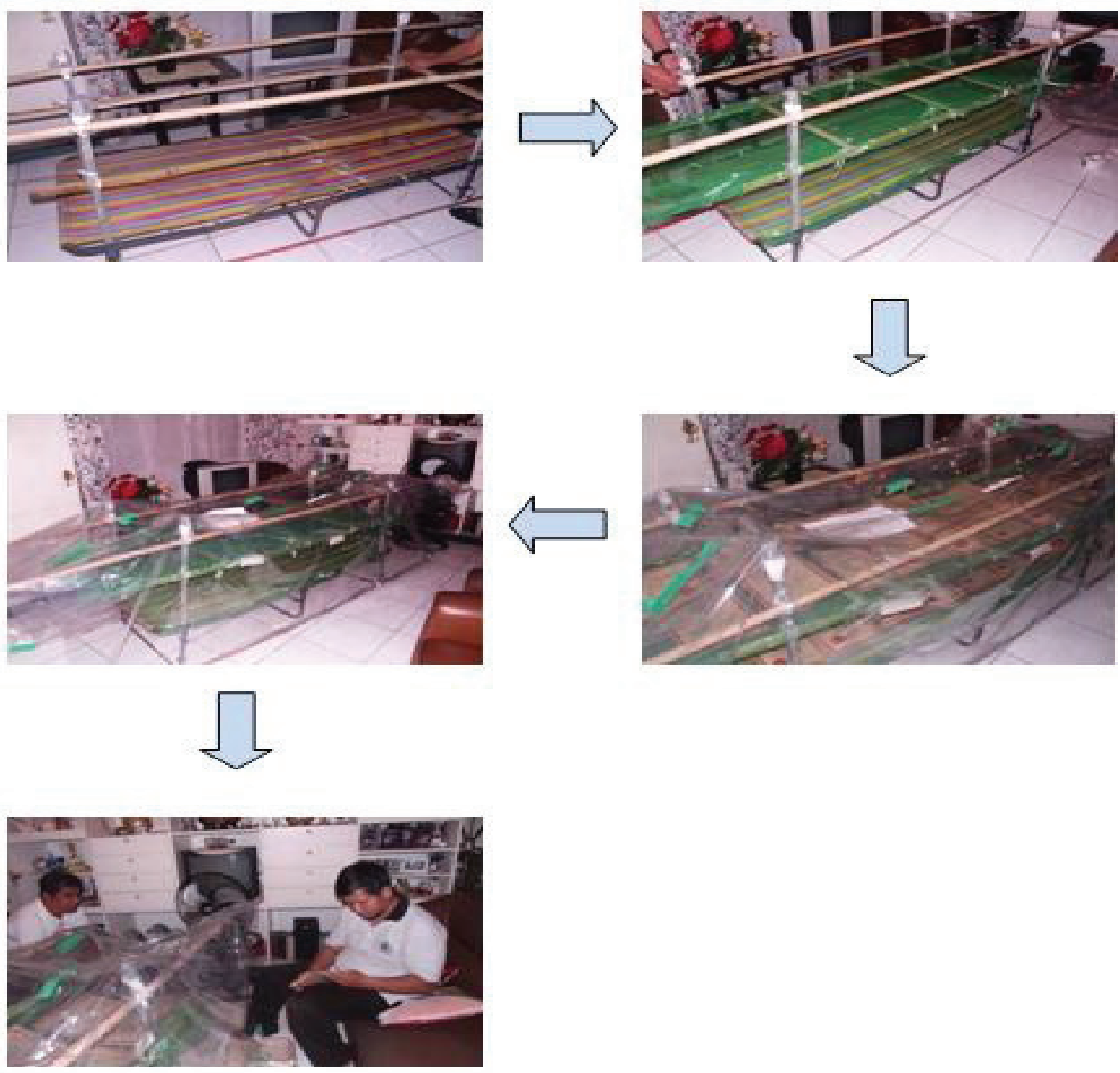

Gambar 12. Ilustrasi proses pemulihan dokumen dengan chamber manual 
- Tahap 7, dokumen yang telah kering kemudian disusun sesuai dengan letaknya dan dimasukkan ke dalam rak yang diselipkan nonwoven sheet antar-dokumennya sehingga tidak menempel ketika lembab. Pada saat ini, sudah ada proses penyelamatan yang lebih canggih dan menghasilkan jumlah dokumen yang terselamatkan jauh lebih banyak dan lebih cepat. Metode tersebut adalah freeze drying. Pada kasus di Filipina, menjadi masalah karena pemerintahnya tidak memiliki mesin penyelamat dokumen menggunakan freezer drying - karena biaya yang mahal dan butuh proses migrasi dokumen. Sebenarnya penggunaan freezer lebih menguntungkan karena dapat: (a) mencegah dan membunuh jamur atau biota yang tumbuh; (b) mencegah terjadinya penebalan atau pembengkakan kertas; (c) menyetabilkan tinta dan pewarna pada kertas; (d) mencegah kertas menempel satu sama lain; dan (e) mengulur waktu untuk perencanaan dan perbaikan pekerjaan.

Hasil dari tahapan penyelamatan dan pemulihan dokumen berdasarkan tahapan di atas, dapat dilihat pada Gambar 13.
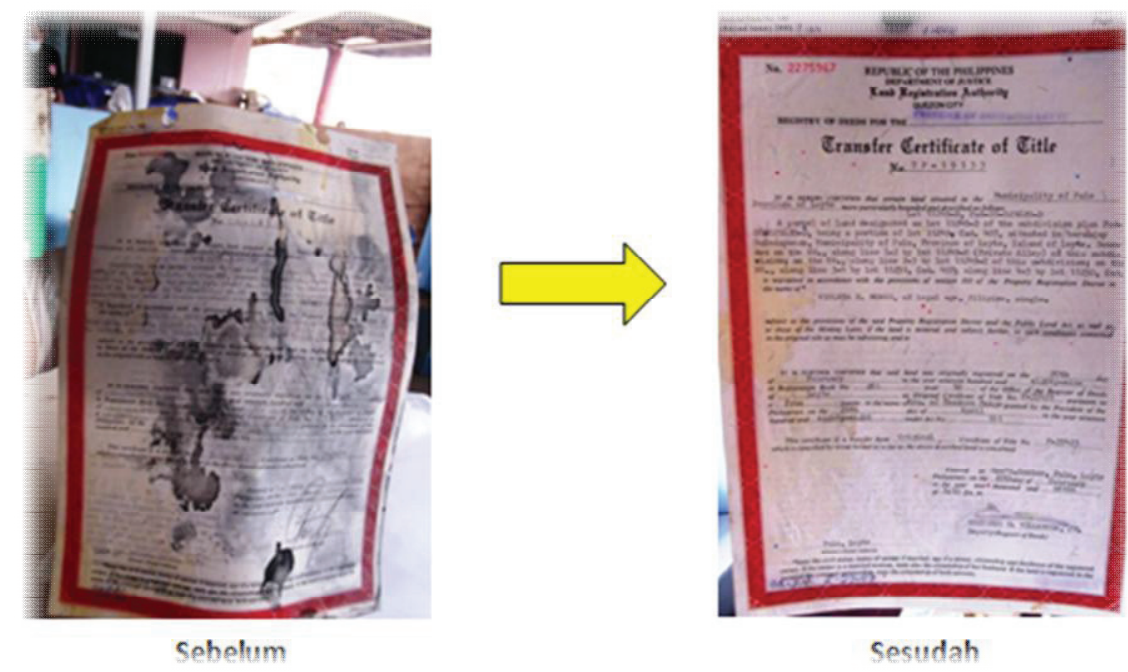

Gambar 13. Hasil penyelamatan dan pemulihan dokumen Sumber: Observasi langsung (2013)

Kegiatan penyebarluasan informasi dilakukan dengan mengundang media televisi setempat dan membuat poster pengetahuan. Kegiatan ini sangat penting karena: (a) dapat digunakan sebagai pertanggungjawaban pekerjaan tim dalam bekerja; (b) sebagai sarana pemberitahuan kepada masyarakat tentang tempat untuk meminta bantuan guna menyelamatkan dokumen; dan (c) merupakan siar kepada dunia untuk ikut berpartisipasi membantu masyarakat yang terkena bencana. Gambar 14 menunjukkan ilustrasi kegiatan penyebarluasan informasi terkait kegiatan penyelamatan dan pemulihan dokumen bencana. 

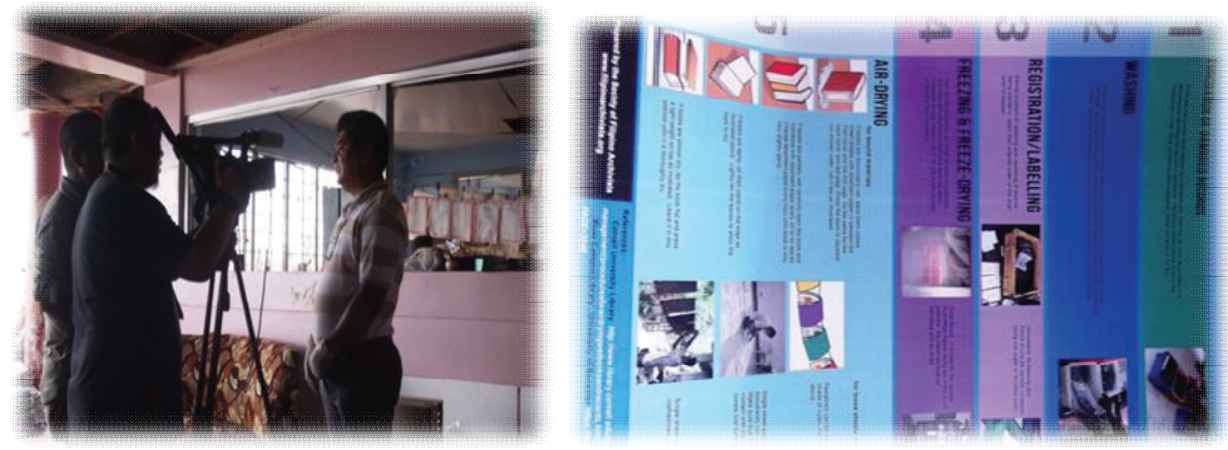

Gambar 14. penyerbarluasan informasi melalui wawancara di media reuters dan poster pengetahuan Sumber: Observasi langsung (2013)

\section{KESIMPULAN}

Bencana topan Haiyan yang melanda Filipina di seluruh wilayah terutama kantor pertanahan dan perpustakaan Tacloban City pada tahun 2013 menimbulkan kerusakan dan kehancuran sarana dan prasarana disekitarnya. Hancur dan rusaknya dokumen penting milik masyarakat yang menjadi identitas aset kepemilikan atas lahan pribadi atau golongan terjadi secara cepat. Kedatangan tim relawan dari berbagai negara yang membantu pemulihan dan penyelamatan dokumen/arsip negara memberi arti penting bahwa manajemen penangulangan bencana merupakan sistem yang komprehensif dan sangat dibutuhkan saat ini. Metode dan cara perbaikan dokumen memberi pengetahuan dan pengalaman belajar bersama - bagaimana ilmu ini dapat digunakan untuk masa datang. Tulisan ini diharapkan dapat menjadi bahan pembelajaran dan memberikan ilmu bagi generasi muda, sehingga mereka tidak ragu lagi ketika harus terjun ke lapangan untuk membantu korban bencana, penyelamatan dan pemulihan dokumen. 


\section{DAFTAR PUSTAKA}

Alayon, s. B., et.al. 2015. For the Record: The Fate of Libraries and Records Offices in The Visayas, Philippines Devastated by the Typhoon Haiyan. Di http://myrepositori.pnm.gov.my/bitstream/123456789/4189/1/CONSALXVI_StephenBA.p df.

Black, S. 2004. When Disaster Strikes. American School Board Journal, 191(7), 36-38.

Clement, David. 1985. Preservation of Library Collection. PX: UNESCO. Conservation and Preservation at the National Library of Indonesia: A Report by the International Revew Team for Conservation and Preservation. Jakarta: Perpustakaan Nasional RI.

Echezona, R. I. 2012. Disaster Management in University Libraries: Perceptions, Problems and Strategies. International Research: Journal of Library and Information Science, 2(1).

Ellis, J. 2007. Lessons Learned: The Recovery of a Research Collection After Hurricane Katrina. Collection Building, 26(4), 108-111.

Fleischer, S. V., \& Heppner, M. J. 2009. Disaster Planning for Libraries and Archives: What You Need to Know and How To Do It. Library \& Archival Security, 22(2), 125-140.

Muir, A., \& Shenton, S. 2002. If the Worst Happens: The Use and Effectiveness of Disaster Plans in Libraries And Archives. Library management, 23(3), 115-123.

Nurjannah, N. 2014. Preservasi dan Konservasi Bahan Pustaka dan Arsip Pasca Tsunami di Badan Arsip dan Perpustakaan Aceh. Disertasi. Yogyakarta: UIN Sunan Kalijaga.

Okello-Obura, C., \& Ssekitto, F. 2011. Records and Information Disaster Preparedness in Selected Organisations in Uganda. ESARBICA Journal, 30, 135.

Rattan, P. 2013. Role of Library and Information Centres in Disaster Management.

Sable, M. H. 1984. The Protection of The Library and Archive: An International Bibliography. Psychology Press.

Ur Rehman, A. 2014. Importance and Measures of Disaster Management in Libraries. European Scientific Journal. 